\title{
Foot problems in patients with systemic lupus erythematosus; under-reported and under-treated?
}

\author{
S Otter ${ }^{1 *}$, S Kumar ${ }^{2}$, P Gow ${ }^{2}$, N Dalbeth ${ }^{3}$, KA Davies ${ }^{4}$, S Panthakalam ${ }^{5}$, K Rome $^{1}$ \\ From Australasian Podiatry Conference 2015 \\ Queensland, Australia. 6-8 May 2015
}

\section{Background}

Foot pathology is common in inflammatory arthritis and the role of the podiatrist in the multidisciplinary care team is well established. However, in systemic lupus erythematosus; (SLE) the need for foot health services and service provision for foot disease is unknown. We set out to determine the perceived need and uptake of foot care services.

\section{Methods}

A 40-item self-administered postal questionnaire was posted to patients with SLE attending adult rheumatology clinics at Auckland and Counties Manukau District Health Boards, Auckland, New Zealand. The questionnaire enquired about the occurrence of foot symptoms and their frequency of assessment, the availability of podiatric services and the usefulness of interventions.

\section{Results}

In total, 107 patients responded with 79\% reporting foot pain caused by their SLE. Half (51\%) of the patients had discussed foot pain with their general practitioner or rheumatologist, and a third (33\%) had difficulty with basic foot care. Respondents reported there was no significant difference in the frequency with which their hands and feet were examined. However, only $33 \%$ had been seen by a podiatrist. Insoles had only been prescribed to a quarter of respondents $(25 \%)$ but only half of those receiving insoles were continuing to wear them and merely two respondents indicated their foot symptoms had been resolved by their insoles. None of the subjects reported that they had been provided with specialist footwear.

\section{Conclusion}

These data suggest that foot problems are common and under-reported in patients with SLE. Health care professionals need to consider a comprehensive foot care plan as part of the holistic management of people with SLE.

\section{Authors' details \\ 'Auckland University of Technology, Auckland, New Zealand. 'Middlemore Hospital, Papatoetoe 2025, New Zealand. ${ }^{3}$ The University of Auckland, Auckland, 1010, New Zealand. " Brighton \& Sussex Medical School, Brighton, BN1 9PX, UK. ${ }^{5}$ Eastbourne District General Hospital, Eastbourne, BN21 2UD, UK.}

Published: 22 September 2015

\section{doi:10.1186/1757-1146-8-S2-031}

Cite this article as: Otter et al.: Foot problems in patients with systemic lupus erythematosus; under-reported and under-treated? Journal of foot and Ankle Research 2015 8(Suppl 2):031.

* Correspondence: simon.otter@aut.ac.nz

${ }^{1}$ Auckland University of Technology, Auckland, New Zealand

Full list of author information is available at the end of the article

Submit your next manuscript to BioMed Central and take full advantage of:

- Convenient online submission

- Thorough peer review

- No space constraints or color figure charges

- Immediate publication on acceptance

- Inclusion in PubMed, CAS, Scopus and Google Scholar

- Research which is freely available for redistribution
() Biomed Central 